Article

\title{
Localized Effects of Coarse Woody Material on Soil Oribatid Communities Diminish over 700 Years of Stand Development in Black-Spruce-Feathermoss Forests
}

\author{
Enrique Doblas-Miranda ${ }^{1, *}$ and Timothy T. Work ${ }^{2}$ \\ 1 CREAF, Cerdanyola del Vallès 08193, Spain \\ 2 NSERC-UQAT-UQAM Chair in Sustainable Forest Management Research Group, \\ Department of Biological Sciences, Université du Québec à Montréal, Montréal, Québec CP 8888, \\ Succursale Centre-ville H3C 3P8, Canada; E-Mail: work.timothy@uqam.ca \\ * Author to whom correspondence should be addressed; E-Mail: e.doblas@creaf.uab.es; \\ Tel.: +34-935-814-664; Fax: +34-935-814-151.
}

Academic Editors: Jarmo Holopainen and Eric J. Jokela

Received: 24 October 2014 / Accepted: 19 March 2015 / Published: 27 March 2015

\begin{abstract}
In the black-spruce clay-belt region of Western Québec, soil nutrients are limited due to paludification. Under paludified conditions, nutrient subsidies from decomposing surface coarse woody material (CWM) may be important particularly during the later stages of ecosystem development when deadwood from senescent trees has accumulated. For soil organisms, CWM can alter microclimatic conditions and resource availability. We compared abundance and species richness of oribatid mites below or adjacent to CWM across a chronosequence which spans $c a$. 700 years of stand development. We hypothesized that oribatid abundance and richness would be greater under the logs, particularly in later stages of forest development when logs may act as localized sources of carbon and nutrients in the paludified substrate. However, oribatid density was lower directly under CWM than adjacent to CWM but these differences were attenuated with time. We suggest that oribatids may be affected by soil compaction and also that such microarthropods are most likely feeding on recently fallen leaf litter, which may be rendered inaccessible by the presence of overlying CWM. This may also explain the progressive decline in oribatid density and diversity with time, which are presumably caused by decreases in litter availability due to self-thinning and Sphagnum growth. This is also supported by changes of different oribatid trophic groups, as litter feeders maintain different numbers relative to CWM with time while more generalist fungi feeders only show differences related to position in the beginning of the succession.
\end{abstract}


Keywords: bryophytes; chronosequence; ecosystem decline; paludification; soil microarthropods

\section{Introduction}

In the prolonged absence of major disturbance, forest ecosystems may pass through a retrogressive phase whereby overall productivity declines in response to a long-term net loss of nutrients such as phosphorus $(\mathrm{P})$ [1,2]. Along with declines in nutrients, retrogression provokes compositional changes in both soil microbes and forest litter, which in turn affects decomposition rates $[1,3,4]$. The effects of reduced productivity in older stands extend further into decomposer-based food webs as evidenced by reductions of soil macroarthropods and nematodes [5]. In some boreal ecosystems, sequestration of nutrients in deep, paludified organic horizons may resemble retrogression in relatively short periods ( $c a$. 1000 years) [6,7]. In these ecosystems, growth of Sphagnum combined with rising water tables and cold temperatures result in an increasing proportion of nutrients immobilized in poorly decomposing organic matter as stands age [8]. Black-spruce (Picea mariana (P. Mill.) B.S.P) feathermoss forests of the clay-belt region of Western Québec are often prone to paludification in the absence of fire [9] and are some of the most nutrient limited forests known [10]. In this region, surface deadwood decreases radically after 260 years after fire (unpublished results). However, buried wood resulting from paludification increases steadily as stands progress to old-growth.

Under such conditions, detrital inputs of coarse woody material (CWM) deposited on the forest floor surface may have localized effects on soils and soil communities. Unlike poorly decomposing Sphagnum [11], mineralization of CWM provides a localized source of carbon (C) [12,13]. In nearby boreal mixedwood forests, the release of nitrogen $(\mathrm{N})$ and $\mathrm{P}$ from CWM occurred in quantities consistent with annual immobilization rates by trees [13]. While these releases of nutrients varied by individual tree species, they were generally greater in later stages of decay, suggesting that successional dynamics and stand development would also be important factors in determining when CWM would influence below ground communities [8]. In agricultural field trials and microcosm experiments, detrital deposition of basic metabolic building blocks such as $\mathrm{C}, \mathrm{N}$ and $\mathrm{P}$ are important drivers for soil food webs [14]. In addition to potential changes in C and nutrients, CWM may directly affect forest soils by modifying soil moisture and temperature $[15,16]$.

Several studies from forest ecosystems have suggested limited effects of potential CWM nutrient releases on soil communities. In early successional aspen (Populus tremuloides Michx.) stands in Eastern Canada, Déchêne and Buddle [17] compared soil mites collected adjacent to and $1 \mathrm{~m}$ from aspen logs. Although they observed slightly significant effects of distance to CWM on richness (higher close to the logs) they did not observe effects on abundance or composition of soil mites. In late successional forests in the Pacific Northwest of the United States, Marra and Edmonds [18] compared soil invertebrates adjacent to and $\sim 1 \mathrm{~m}$ from western hemlock (Tsuga heterophylla (Raf.) Sarg.) logs in intermediate decay stages. They found that soil depth and stand management were more important factors determining the density, species richness and composition of soil invertebrates than was the location relative to individual pieces of CWM [18]. Neither of these studies included soil communities 
located beneath CWM. However, Evans et al. [19], which compared soil microarthropods beneath and adjacent to red beech (Nothofagus fusca (Hook.f.) Oerst.) CWM in New Zealand. They concluded that for several taxa, proximity to CWM was an important factor, although the limited taxonomic resolution of this study significantly curtails inferences as to how CWM is affecting soil biota [19]. While these studies suggest that belowground effects of CWM on soil mites may be limited, all provide individual "snapshots" of soil communities during a specific period within different successional processes. Greater understanding of the relevance of CWM for belowground biota necessitates studies that reflect longer-term deadwood dynamics and stand succession.

Here, we compare below-ground assemblages of oribatid mites collected below and adjacent to CWM throughout a chronosequence of black spruce stands spanning more than 700 years of stand development. Unlike previous studies, where available soil $\mathrm{C}$ and nutrients are relatively accessible to detrital consumers, in older, heavily paludified stands where retrogression is occurring, $\mathrm{C}$ and nutrients are immobilized by abundant Sphagnum mosses. If CWM provides substantial nutrient and C subsidies to underlying soil communities in paludified forests, we hypothesize soil oribatids should be more abundant and diverse in the forest floor underlying the CWM within later stages of forest development affected by paludification.

\section{Materials and Methods}

\subsection{Study Site}

In the boreal claybelt region of Western Québec, stand-replacing wildfires are the principal natural disturbance. Following wildfire, stand development is characterized by changes in stand-structure rather than shifts in overstory species composition [20,21]. Older stands have multiple cohorts of trees, numerous canopy gaps and very thick organic horizons $(>1 \mathrm{~m})$ composed of Sphagnum mosses [22,23]. In later, old-growth stages bryophytes cover much of the forest floor in some cases nearly covering CWM by aggressive growth of Spahgnum spp. [24,25]. We sampled soil microarthropods from a chronosequence of 10 black spruce (Picea mariana) stands $\left(49^{\circ} 00^{\prime}-50^{\circ} 00^{\prime} \mathrm{N}\right.$; $78^{\circ} 30^{\prime}-79^{\circ} 30^{\prime} \mathrm{W}$ ). These stands ranged from 60-718 years' time since fire (TSF) and together represented all major structural phases of stand development in this region [8,21] except stand initiation: (1) stem exclusion, with stand growth and self-thinning; (2) old growth, with decreasing tree abundance due to paludification and high structural diversity; and (3) retrogression, where overall productivity declines (Table 1). The soils in this region are characterized as organic with clay surficial deposits [26]. Mean annual temperature is $-0.7^{\circ} \mathrm{C}$ and annual precipitation is $905.5 \mathrm{~mm}$ [27]. 
Table 1. Characteristics of a chronosequence black-spruce/feather moss stands used in this study ${ }^{1}$.

\begin{tabular}{cccccc}
\hline Stand & $\begin{array}{c}\text { Time } \\
\text { since fire }\end{array}$ & $\begin{array}{c}\text { Chronosequence } \\
\text { stage }\end{array}$ & $\begin{array}{c}\text { Basal area } \\
\left(\mathbf{m}^{2} / \mathbf{h a}\right)\end{array}$ & $\begin{array}{c}\text { CWM volume } \\
\left(\mathbf{m}^{\mathbf{3}} \mathbf{h a} \mathbf{)}\right.\end{array}$ & $\begin{array}{c}\text { Bryophyte } \\
\text { thickness }(\mathbf{c m})\end{array}$ \\
\hline N4 & 60 & 1 & 39.59 & 7.44 & 26.65 \\
N23 & 94 & 1 & 46.00 & 19.73 & 15.15 \\
S1 & 95 & 1 & 45.03 & 5.66 & 22.40 \\
Ch75 & 133 & 2 & 25.93 & 8.67 & 44.70 \\
N18 & 134 & 2 & 35.55 & 8.53 & 46.40 \\
N8 & 183 & 2 & 34.51 & 24.92 & 43.15 \\
POP & 183 & 2 & 13.86 & 53.61 & 48.05 \\
L22 & 283 & 2 & 21.25 & 57.18 & 49.45 \\
N50 & 373 & 2 & 19.65 & 47.80 & 48.30 \\
N6 & 718 & 3 & 21.70 & 33.84 & 58.75 \\
\hline
\end{tabular}

${ }^{1}$ Additional information on stands is available [21,23].

\subsection{Sampling Design}

We collected paired soil cores $(6 \mathrm{~cm}$ diameter, $7 \mathrm{~cm}$ depth) below and $50 \mathrm{~cm}$ adjacent to black spruce CWM at 2 locations within each stand resulting in the collection of 40 soil cores. Logs ranged between 5.5 and $16.4 \mathrm{~cm}$ diameter (mean $10.3 \mathrm{~cm}$ ) and included different decay stages (mean wood density $0.28 \mathrm{~g} / \mathrm{cm}^{3}$ ). Microarthropods were extracted by washing soil cores [28]. In boreal forests, earthworms are scarce while soil microarthropods are important detrital consumers that are linked with decomposition in soils [29]. Samples were soaked in $\mathrm{KOH}$ solution to separate microarthropods from the substrate, washed and sieved through $500 \mu \mathrm{m}$ and $250 \mu \mathrm{m}$ filters. All specimens were conserved in $70 \%$ ethanol. Arthropods were sorted from the remaining debris, counted and classified, although due to the scarce abundance of most groups only oribatids were used for research purposes. Oribatid mites were identified to the species level, e.g., [30-32], and the most abundant species where classified into four trophic groups; litter feeders, fungi feeders, plant tissue [33-37] and unspecified, when species identification or trophic level could not be assigned (Appendix Table A1).

For each pair of soil cores, we recorded diameter and wood density of the log covering the soil core. A cylindrical sample of each log was collected to measure wood density. We dried each sample to constant mass then measured volume using water-displacement [38]. We also measured sample moisture (obtained gravimetrically) for all samples. We also used tree basal area, CWM volume and thickness of the bryophyte layer within each stand for community level analyses (Table 1). These data were provided by J. Jacobs.

\subsection{Statistical Analyses}

We compared adult oribatid densities (number of species/gram of dry soil) using a series of hierarchical linear mixed models. In these models, position relative to CWM (under or adjacent) and age of the stand were fixed factors and location was the random factor [39]. We compared densities of all oribatid species combined as four separate feeding groups. In these models we log-transformed both oribatid density and stand age. Linear mixed models were fit by restricted maximum likelihood ( $\mathrm{R}$ version 2.11.1) [40]. 
We estimated species richness of oribatids using individual-based rarefaction [41]. Rarefaction curves were produced from pooled abundances of samples taken below and adjacent to CWM and among three different stand stages (based in forest development stages; 60-95 years after fire or first stage of stand development, 133-373 years or old growth, 718 years or long term; Table 1) using the Vegan Community Ecology Package (R package version 1.13).

We also compared oribatid density within each soil core with soil moisture, diameter of logs and density of wood (log variables only for soil cores taken under CWM) using Pearson-product moment correlations. Correlation analysis was also used to test for relationships between oribatid density and basal area, CWM volume and bryophyte thickness within each stand.

\section{Results}

\subsection{Soil Microarthropod Community}

We collected 1180 Acari (824 Oribatida including immature stages), 292 Collembola, and 83 other microarthropods composed of Thysanoptera, Homoptera (Aphidae), and larval stages of Coleoptera and Diptera. A total of 704 adult oribatid mites were collected, representing 39 different species (Appendix Table A1). The most abundant species was Atropacarus striculus (C.L. Koch, 1835), a litter feeder Ptyctima, followed by two species of the genera Nothrus and Hermannia, respectively. Scheloribates pallidulus (C.L. Koch, 1841), which feeds on plant tissues, and Eniochthonius minutissimus (Berlese, 1903), a typical fungi feeder, were also very abundant.

\subsection{Oribatid Distribution}

Position relative to CWM and, to a lesser extent, stand age were important factors determining overall mite density (Table 2). As it is shown in Figure 1, mite densities were higher adjacent to CWM than under CWM (Table 2). Although density of oribatids decreases with time in both positions relative to CWM, the interaction of both variables, position and age, was not significant (Table 2 and Figure 1).

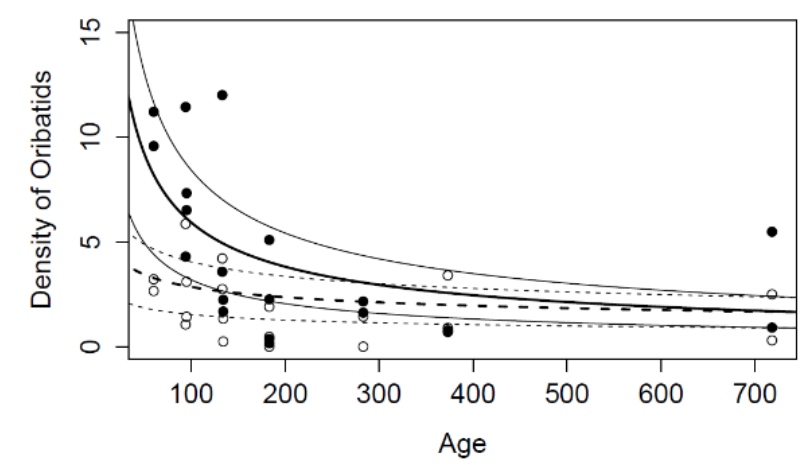

Figure 1. Total density of adult oribatids (individuals/g of dry substrate) plotted against stand age (years since fire). Black dots correspond to adjacent position relative to coarse woody material (CWM) and open circles to samples under CWM. The solid line corresponds to the line of predicted values for adjacent samples while the dashed line corresponds with the predicted values from the mixed model for samples under CWM. Thinner lines represent error intervals for each line of predicted values. 
Oribatid species richness estimated from rarefaction curves was also higher in samples adjacent to CWM than those taken beneath CWM, although these differences were relatively small (Figure 2a) and reflect the larger numbers of individuals found in samples collected adjacent to CWM. Although oribatid species richness increased with stand development from first (Stage 1) to old growth stages (Stage 2), it clearly decreases at the long-term stage (Stage 3) (Figure 2b).

Table 2. Coefficients of the linear mixed effect model fit by restricted maximum likelihood for adult oribatid densities (log transformed) including age of stand ( $\log$ transformed), position of sample relative to CWM and the interaction as explanatory variables.

\begin{tabular}{|c|c|c|c|c|c|}
\hline Parameter & Value & Std. Error & $\mathrm{DF} * *$ & $t$-value & $p$-value \\
\hline \multicolumn{6}{|c|}{ Total Oribatids } \\
\hline Intercept (Position Adjacent *) & 4.71 & 1.22 & 27 & 3.85 & 0.0007 \\
\hline Age & -0.64 & 0.23 & 8 & -2.71 & 0.0268 \\
\hline Position Under & -2.41 & 1.15 & 27 & -2.10 & 0.0451 \\
\hline Age:Position Under & 0.36 & 0.22 & 27 & 1.65 & 0.1103 \\
\hline \multicolumn{6}{|c|}{ Litter feeders } \\
\hline Intercept (Position Adjacent) & 1.86 & 0.77 & 27 & 2.41 & 0.0232 \\
\hline Age & -0.25 & 0.15 & 8 & -1.66 & 0.1344 \\
\hline Position Under & -0.95 & 0.61 & 27 & -1.55 & 0.1320 \\
\hline Age:Position Under & 0.11 & 0.12 & 27 & 0.96 & 0.3439 \\
\hline \multicolumn{6}{|c|}{ Fungi feeders } \\
\hline Intercept (Position Adjacent) & 2.23 & 0.57 & 27 & 3.88 & 0.0006 \\
\hline Age & -0.37 & 0.11 & 8 & -3.36 & 0.0100 \\
\hline Position Under & -2.36 & 0.76 & 27 & -3.12 & 0.0043 \\
\hline Age:Position Under & 0.42 & 0.14 & 27 & 2.92 & 0.0070 \\
\hline
\end{tabular}

* Refers to the reference condition used in linear mixed model for presentation of fixed effect parameters;

** refers to degrees of freedom associated with the denominator.

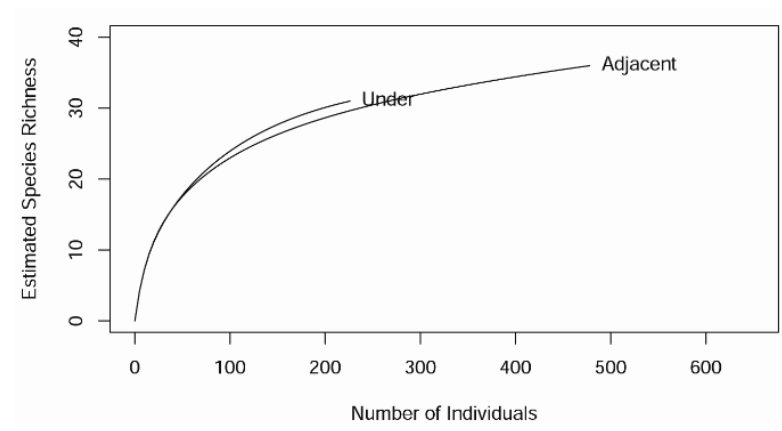

(a)

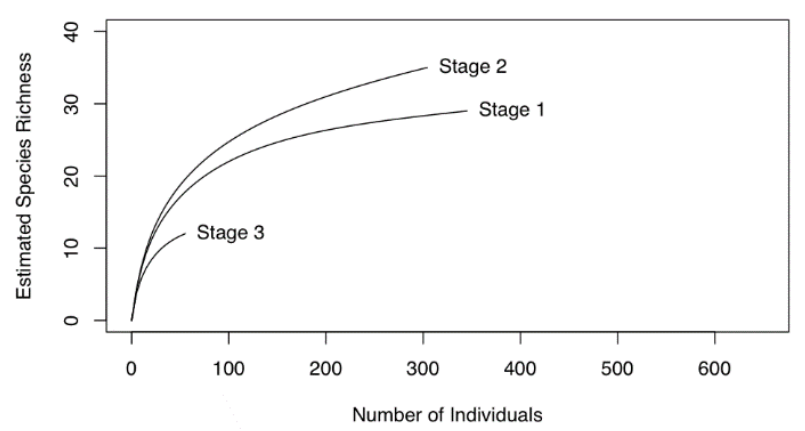

(b)

Figure 2. Rarefaction curves depicting estimated number of oribatid species per number of individuals sampled grouped among (a) both under and adjacent CWM positions and (b) among the three chronosequence stages (Stage 1: 60-95 years after fire. Stage 2: 133-373 years. Stage 3: 718 years). Standard error bars for these rarefaction curves overlap through most of the range and are omitted for clarity. 
When densities of the different oribatid trophic groups were compared between both positions relative to CWM and stand age, only litter and fungi feeders showed significant slopes (Table 2). Fungal feeders were less abundant under CWM than adjacent to CWM and decreased with stand age with a pronounced decline in the first stage followed by a steady decrease during the old-growth phase (Figure 3). We also observed a significant interaction between position and stand age whereby differences in fungal feeders relative to CWM diminish as stands age (Figure 3). Density of litter feeders did not significantly differ in position relative to CWM or with stand age (Table 2). However, while not strongly supported in our model, our data suggests that density of litter feeding is less under CWM (Figure 3).

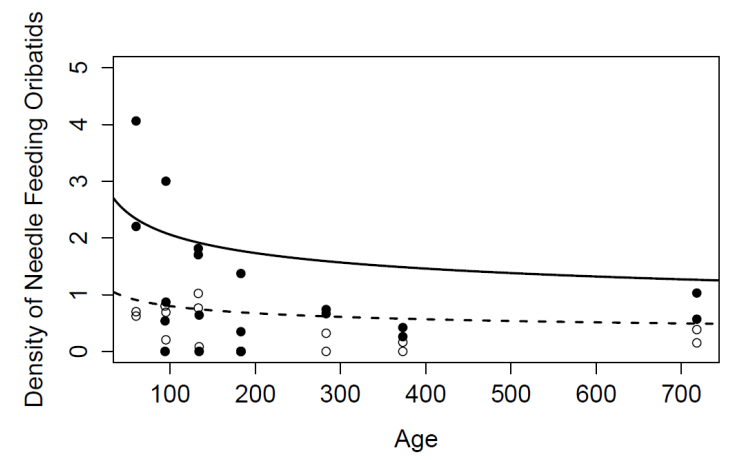

(a)

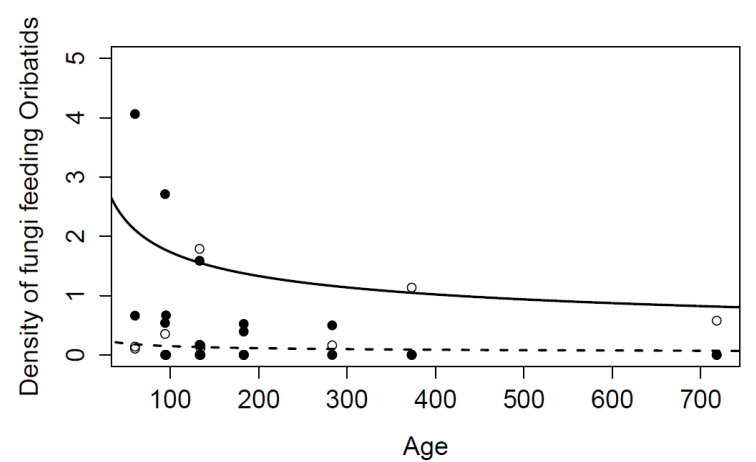

(b)

Figure 3. Density (individuals/g of dry substrate) of (a) litter feeder and (b) fungi feeder oribatids plotted against stand age (years since fire). Black dots correspond to adjacent position relative to CWM and open circles to samples under CWM. The solid line corresponds to the line of predicted values for adjacent samples while the dashed line corresponds with the predicted values from the mixed model for samples under CWM.

\subsection{Microclimatic and Environmental Factors Related to Oribatid Density}

Oribatid abundance in soil cores collected underneath CWM was negatively correlated with CWM diameter but showed no relation with wood density (Table 3). Oribatid density was positively correlated with moisture (Table 3), meaning that higher moisture showed higher density of oribatids. Moisture was lower in samples collected under CWM than those collected in adjacent exposed forest floor (mean moisture under CWM was $75.7 \%$ versus $80.3 \%$ in adjacent samples). At the stand level, oribatid density was only significantly correlated with CWM volume (Table 4). Where log volume was greater, fewer oribatids were found. 
Table 3. Pearson-product moment correlations between adult oribatid density (log transformed) and environmental variables measured in individual soil cores.

\begin{tabular}{cccc}
\hline \multirow{2}{*}{ Variable } & \multicolumn{3}{c}{ Oribatid density (individuals/g of } \\
& \multicolumn{3}{c}{ dry substrate) } \\
\hline & Rho* & $t$-value & $p$-value \\
CWM Diameter $^{1}$ & -0.463 & -2.153 & 0.04599 \\
CWM Density $^{1}$ & -0.014 & -0.059 & 0.95360 \\
Moisture $^{2}$ & 0.343 & 2.2202 & 0.03261 \\
\hline
\end{tabular}

${ }^{1}$ Spearman tests based on $d f=17$ with only samples collected from beneath CWM included in the analysis;

2 Spearman tests based on $d f=37$ with all samples used in the analysis; * Spearman's rank correlation coefficient.

Table 4. Pearson-product moment correlations between adult oribatid density (log transformed) and stand-level measurements for basal area, volume of coarse woody material and organic layer thickness (tests based on $d f=8$ ).

\begin{tabular}{cccc}
\hline Variable & \multicolumn{3}{c}{ Oribatid density (individuals/g of } \\
dry substrate)
\end{tabular}

* Spearman's rank correlation coefficient.

\section{Discussion}

In our study, abundance and richness of oribatids were greatly reduced compared to other temperate and boreal forest ecosystems, e.g., [42-44]. For particular taxonomic groups of arthropods such as ground beetles, black spruce forests undergoing paludification have markedly reduced densities [45,46]. Moreover, forest retrogression has been linked to further reductions of already dwindling population numbers, e.g., [5].

Over the long timeframe encompassed with our chronosequence, we observed a decrease in oribatid density and species richness that is concordant with a generalized community response during retrogression [5,7]. Studies of forest microarthropods that span shorter ecological timeframes have produced a variety of responses in density and species richness. For example, in spruce forests between 25 and 180 years, the temporal pattern of oribatid abundance showed no differences [47], declines [48], or increases, which were attributed to temporal variations in soil characteristics [49]. These studies showed less variability in species richness among successional stages $[47,48]$ than ours. As we expected, microarthropods should indirectly respond to the overall productivity decline due to the sequestration of nutrients in deep paludified horizons [6]. However, contrary to our expectations, it seems that $\mathrm{CWM}$ does not provide an alternative source of $\mathrm{C}$ and nutrients to these soil arthropods, even in later stages of ecosystem development.

In contrast, in our study the density of soil oribatids living under CWM were reduced even in the later, more retrogressive stages of ecosystem development. This is in contrast to previous studies, which 
have demonstrated few direct effects of CWM on soil fauna communities [17-19]. In our initial hypothesis, we expected CWM to be a significant source of $\mathrm{C}$ and other nutrients, which could in turn influence microbial activity directly beneath [50] and potentially increase abundance and diversity of microbial grazers [51]. However, nutrient releases from CWM may be being rapidly immobilized by underlying Sphagnum [52,53], potentially limiting any sort of enrichment to any underlying trophic levels and minimizing resource availability beneath or adjacent to CWM. Increased decay of CWM has been related to increased abundance and diversity of microarthropods inhabiting inside the $\log [51,54]$. However, wood density, a direct measure of wood decay and a strong proxy of palatability of wood to specialist feeders, did not affect soil mites in our study. This suggests that decomposition effects are likely limited only to resident species within logs and not to underlying soil communities further confirming trends reported elsewhere [54,55]. This further limits the likelihood that increases in buried wood commonly reported in paludified stands [24] would affect soil communities outside of decaying logs.

Differences in oribatid abundances could be also related to moss compaction due to the weight of the CWM. Compaction could affect the volume of pores and spaces among mosses were the mites inhabit, which are related to mite abundance [56]. Although the selected logs were not big enough (between 5.5 and $16.4 \mathrm{~cm}$ diameter) to greatly affect moss compaction, we cannot readily dismiss compaction as a possible explanation for differences in oribatid abundance, especially considering the significant effect of $\log$ diameter on oribatid numbers.

Finally, we doubt moisture is related to differences in spatial distribution relative to CWM in these black-spruce feathermoss ecosystems. While drought has been shown to be a critical factor affecting oribatid mite distribution [57,58], samples both adjacent and under CWM showed very high moisture levels (between $62 \%$ and $91 \%$ of water content) and are not likely to be a limiting factor for these microarthropods [59]. While temperature was not measured for each sample, soil temperature in the study area is low [23] but within the reported tolerance of oribatids [59].

We propose an alternative hypothesis where oribatids may be preferentially responding to litter deposition. Oribatids inhabiting the soil have, in most cases, preferences for decaying litter [35]. More specifically, certain oribatids (as E. minutissimus and most Ptyctima) depend on fungi associated with forest litter as a source of calcium for the formation of their cuticle [36]. In paludified forests, litter deposition decreases with losses in stand productivity that occur as stands age. Further losses of leaf litter will be incurred as Sphagnum growth rates increase. These factors conspire to create a limited window of accessibility to litter deposited on the surface. If litter deposition on the forest floor surface is indeed important for oribatids, CWM may effectively block access to deposited needles similar to an umbrella. The negative correlation between $\log$ diameter and oribatid abundance supports this hypothesis as larger pieces of CWM present a bigger obstacle for deposition of new litter.

The interaction between stand age and position relative to CWM could be also explained by a decrease in the importance of the umbrella effect of CWM. Fungi feeders show differences of position only in the beginning of the succession, when fungi growing on litter are most likely rich and abundant. This heterogeneous trophic group is in fact considered to feed also partly on decomposing litter material [35]. However, fungi feeders do not show differences in later states of ecosystem development, when litter is scarce and probably poor in nutrient content. Rather, we hypothesize that the large quantities of mycorrhizal fungi present in CWM and on roots present throughout succession in the black spruce [60] 
allows fungi feeders to maintain the same levels of abundance in both positions in later stages of stand development.

\section{Conclusions}

Our results suggest limited influence of CWM as a source of $\mathrm{C}$ and nutrients or as a microhabitat refuge to forest floor oribatids in black spruce-feather moss forests prone to paludification. Differences in oribatid density relative to CWM may be related to a combination of soil compaction due to logs weight and differences in food availability between the substrate under and adjacent to the logs. Moreover, different distribution patterns between litter and fungi feeders as well as the long-term decreases in oribatid abundance and diversity suggest that oribatids are responding primarily to litter supply rather than CWM.

\section{Acknowledgements}

We would like to thank Jenna Jacobs and Nicole Fenton for their help during the study, and also Christina Elliott and Alexis Latraverse for their help during the field work.

\section{Author Contribution}

Enrique Doblas-Miranda and Timothy Work conceived and designed the study; Enrique Ddoblas-Miranda performed the field and laboratory work, including oribatid identification; Enrique Doblas-Miranda and Timothy Work analyzed the data and wrote the paper.

\section{Conflicts of Interest}

The authors declare no conflict of interest.

\section{Appendix}

Table A1. Number of individuals and relative abundance of the 39 Oribatid species found and trophic guild of the 8 most abundant species.

\begin{tabular}{|c|c|c|c|c|}
\hline Family & Species & $N$ & $\begin{array}{c}\text { Relative } \\
\text { Abundance \% }\end{array}$ & $\begin{array}{c}\text { Trophic } \\
\text { guild }\end{array}$ \\
\hline Hypochthoniidae & Hypochthonius rufulus C.L. Koch, 1835 & 4 & 0.57 & \\
\hline Eniochthoniidae & Eniochthonius minutissimus (Berlese, 1903) & 55 & 7.81 & Fungi \\
\hline \multirow{2}{*}{ Phthiracaridae } & Atropacarus striculus (C.L. Koch, 1835) & 111 & 15.77 & Litter \\
\hline & Phthiracarus sp. & 17 & 2.41 & \\
\hline Oribotritiidae & Protoribotritia canadaris Jacot, 1938 & 9 & 1.28 & \\
\hline Euphthiracaridae & Rhysotritia ardua (C.L. Koch, 1841) & 40 & 5.68 & Litter \\
\hline Nothridae & Nothrus sp. & 80 & 11.36 & Unspecif. \\
\hline \multirow{2}{*}{ Camisiidae } & Camisia lapponica (Trägårdh, 1910) & 11 & 1.56 & \\
\hline & Camisia sp. 2 & 6 & 0.85 & \\
\hline Trhypochthoniidae & Trhypochthonius tectorum (Berlese, 1896) & 27 & 3.84 & \\
\hline
\end{tabular}


Table A1. Cont.

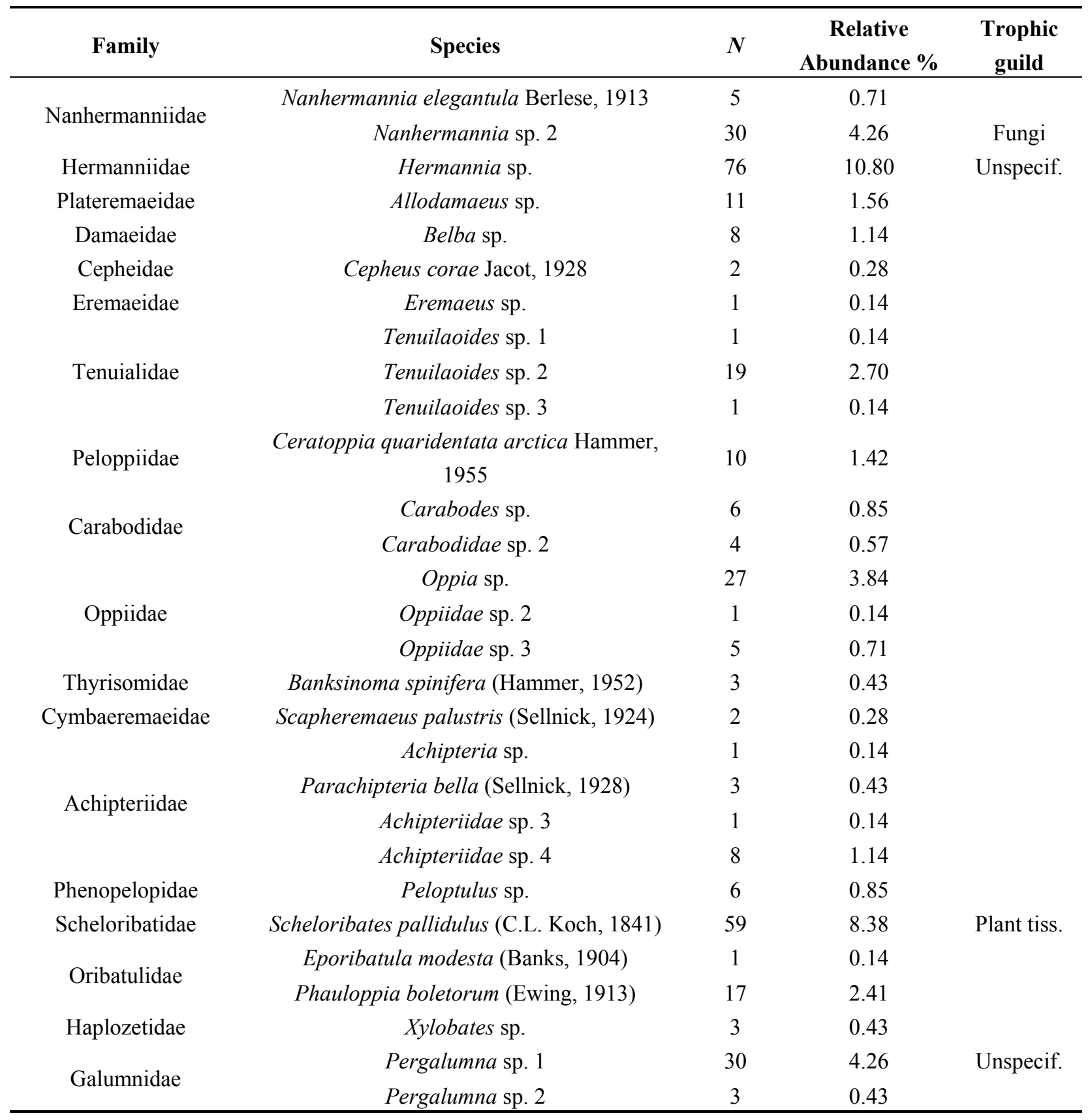

\section{References}

1. Wardle, D.A.; Walker, L.R.; Bardgett, R.D. Ecosystem properties and forest decline in contrasting long-term chronosequences. Science 2004, 305, 509-513.

2. Lagerström, A.; Esberg, C.; Wardle, D.A.; Giesler, R. Soil phosphorus and microbial response to a long-term wildfire chronosequence in northern Sweden. Biogeochemistry 2009, 95, 199-213.

3. Wardle, D.A.; Bardgett, R.D.; Walker, L.R.; Bonner, K.I. Among- and within-species variation in plant litter decomposition in contrasting long-term chronosequences. Funct. Ecol. 2009, 23, 442-453. 
4. Peltzer, D.A.; Wardle, D.A.; Allison, V.J.; Baisden, W.T.; Bardgett, R.D.; Chadwick, O.A.; Condron, L.M.; Parfitt, R.L.; Porder, S.; Richardson, S.J.; Turner, B.L.; Vitousek, P.M.; Walker, J.; Walker, L.R. Understanding ecosystem retrogression. Ecol. Monogr. 2010, 80, 509-529.

5. Doblas-Miranda, E.; Wardle, D.A.; Peltzer, D.A.; Yeates, G.W. Changes in the community structure and diversity of soil invertebrates across the Franz Josef Glacier chronosequence. Soil Biol. Biochem. 2008, 40, 1069-1081.

6. Wardle, D.A.; Hörnberg, G.; Zackrisson, O.; Kalela-Brundin, M.; Coomes, D.A. Long-term effects of wildfire on ecosystem properties across an island area gradient. Science 2003, 300, 972-975.

7. Williamson, W.M.; Wardle, D.A.; Yeates, G.W. Changes in soil microbial and nematode communities during ecosystem decline across a long-term chronosequence. Soil Biol. Biochem. 2005, 37, 1289-1301.

8. Simard, M.; Lecomte, N.; Bergeron, Y.; Bernier, P.Y.; Paré, D. Forest productivity decline caused by successional paludification of boreal soils. Ecol. Appl. 2007, 17, 1619-1637.

9. Lavoie, M.; Paré, D.; Fenton, N.; Groot, A.; Taylor, K. Paludification and management of forested peatlands in Canada: A literature review. Environ. Rev. 2005, 13, 21-50.

10. Van Cleve, K.; Dyrness, C.T.; Viereck, L.A.; Fox, J.; Chapin, F.S.; Oechel, W. Taiga ecosystems in interior Alaska. BioScience 1983, 33, 39-44.

11. Brock, T.B.C.; Bregman, R. Periodicity in growth, productivity, nutrient content and decomposition of Sphagnum recurvum var. mucronatum in a fen woodland. Oecologia 1989, 80, 44-52.

12. Laiho, R.; Prescott, C.E. Decay and nutrient dynamics of coarse woody debris in northern coniferous forest: A synthesis. Can. J. For. Res. 2004, 34, 763-777.

13. Brais, S.; Paré, D.; Lierman, C. Tree bole mineralization rates of four species of the Canadian eastern boreal forest: Implications for nutrient dynamics following stand-replacing disturbances. Can. J. For. Res. 2006, 36, 2331-2340.

14. Moore, J.C.; deRuiter, P.C.; Hunt, H.W.; Coleman, D.C.; Freckman, D.W. Microcosms and soil ecology: Critical linkages between field studies and modelling food webs. Ecology 1996, 77, 694-705.

15. Means, J.E.; MacMillan, P.C.; Cromack, K., Jr. Biomass and nutrient content of Douglas-fir logs and otehr detrital pools in an old growth forest. Can. J. For. Res. 1992, 22, 1536-1546.

16. Brais, S.; Sadi, F.; Bergeron, Y.; Grenier, Y. Coarse woody debris dynamics in a post-fire jack-pine chronosequence and its relation with site productivity. For. Ecol. Manag. 2005, 220, 216-226.

17. Déchêne, A.D.; Buddle, C.M. Decomposing logs increase oribatid mite assemblage diversity in mixedwood boreal forest. Biodivers. Conserv. 2010, 19, 237-256.

18. Marra, J.L.; Edmonds, R.L. Effects of coarse woody debris and soil depth on the density and diversity of soil invertebrates on clearcut and forested sites on the Olympic Peninsula, Washington. Environ. Entomol. 1998, 27, 1111-1124.

19. Evans, A.M.; Clinton, P.W.; Allen, R.B.; Frampton, C.M. The influence of logs on the spatial distribution of litter-dwelling invertebrates and forest floor processes in New Zealand forests. For. Ecol. Manag. 2003, 184, 251-262. 
20. Harper, K.A.; Bergeron, Y.; Drapeau, P.; Gauthier, S.; De Grandpré, L. Structural development following fire in black spruce boreal forest. For. Ecol. Manag. 2005, 206, 293-306.

21. Lecomte, N.; Simard, M.; Fenton, N.; Bergeron, Y. Fire severity and long-term ecosystem biomass dynamics in coniferous boreal forests of eastern Canada. Ecosystems 2006, 9, 1215-1230.

22. Crawford, R.M.M.; Jeffree, C.E.; Rees, W.G. Paludification and forest retreat in northern oceanic environments. Ann. Bot. 2003, 91, 213-226.

23. Fenton, N.J.; Bergeron, Y. Facilitative succession in a boreal bryophyte community driven by changes in available moisture and light. J. Veg. Sci. 2006, 17, 65-76.

24. Hagemann, U.; Moroni, M.T.; Makeschin, F. Deadwood abundance in Labrador high-boreal black spruce forests. Can. J. For. Res. 2009, 39, 131-142.

25. Dynesius, M.; Gibb, H.; Hjältén, J. Surface covering of downed logs: Drivers of a neglected process in dead wood ecology. PLoS ONE 2010, 5, e13237.

26. Gauthier, S.; De Grandpré, L.; Bergeron, Y. Differences in forest composition in two boreal forest ecoregions of Quebec. J. Veg. Sci. 2000, 11, 781-790.

27. Environment Canada. Canadian Climate Normals or Averages 1971-2000. National Climate Data and Information Archive, 2000. Available online: http://www.climate.weatheroffice.ec.gc.ca /climate_normals/index_e.html (accessed on 21 June 2010).

28. Clayton, M.; Humble, L. Microarthropod Voucher Specimens; Canadian Forest Service: Victoria, BC, Canada, 1999.

29. Krivolutsky, D.A. The Oribatid Mites; Naukaî: Moscow, Russia, 1995.

30. Balogh, J. The Oribatid Genera of the World; Académiai Kiadó: Budapest, Hungary, 1972.

31. Niedbała, W. Ptyctimous Mites (Acari, Oribatida) of the Nearctic Region; Monographs of the Upper Silesian Museum 4: Bytom, Poland, 2002.

32. Norton, R.A.; Behan-Pelletier, V.M. Eniochthonius Mahunkai sp. n. (Acari: Oribatida: Enionchthoniidae), from north american peatlands, with a redescription of Eniochthonius and key to north american species. Acta Zool. Acad. Sci. Hung. 2007, 53, 295-333.

33. Karg, W. The armoured mite Scheloribates pallidulus C.L. Koch as a pest of cucumber crops under glass and plastic covers. Arch. Phytopathol. Plant Prot. 1984, 20, 181-183.

34. Siepel, H. Niche relationships between two panphytophagous soil mites, Nothrus silvestris Nicolet (Acari, Oribatida, Nothridae) and Platynothrus peltifer (Koch) (Acari, Oribatida, Camisiidae). Biol. Fert. Soils 1990, 9, 139-144.

35. Schneider, K.; Migge, S.; Norton, R.A.; Scheu, S.; Langel, R.; Reineking, A.; Maraun, M. Trophic niche differentiation in soil microartropods (Oribatida, Acari): Evidence from stable isotope ratios $\left({ }^{15} \mathrm{~N} /{ }^{14} \mathrm{~N}\right)$. Soil Biol. Biochem. 2004, 36, 1769-1774.

36. Norton, R.A.; Behan-Pelletier, V.M. Calcium carbonate and calcium oxalate as cuticular hardening agents in oribatid mites (Acari: Oribatida). Can. J. Zool. 1991, 69, 1504-1511.

37. Oliveira, A.R.; de Moraes, G.J.; Ferraz, L.C. Consumption rate of phytonematodes by Pergalumna sp. (Acari: Oribatida: Galumnidae) under laboratory conditions determined by a new method. Exp. Appl. Acarol. 2007, 41, 183-189.

38. Robert, E.; Brais, S.; Harvey, B.D.; Greene, D. Seedling establishment and survival on decaying logs in boreal mixedwood stands following a mast year. Can. J. For. Res. 2012, 42, 1446-1455. 
39. Zuur, A.; Ieno, E.N.; Walker, N.; Saveliev, A.A.; Smith, G.M. Mixed Effects Models and Extensions in Ecology with R; Springer: New York, NY, USA, 2009.

40. R Development Core Team. R: A Language and Environment for Statistical Computing; R Foundation for Statistical Computing: Vienna, Austria, 2010.

41. Colwell, R.K.; Chao, A.; Gotelli, N.J.; Lin, S.-Y.; Mao, C.X.; Chazdon, R.L.; Longino, J.T. Models and estimators linking individual-based and sample-based rarefaction, extrapolation and comparison of assemblages. J. Plant. Ecol. 2012, 5, 3-21.

42. Arroyo, J.; Kenny, J.; Bolger, T. Variation between mite communities in Irish forest types-Importance of bark and moss cover in canopy. Pedobiologia 2013, 56, 241-250.

43. Farska, J.; Prejzkova, K.; Rusek, J. Management intensity affects traits of soil microarthropod community in montane spruce forest. Appl. Soil Eco. 2014, 75, 71-79.

44. Zaitsev, A.S.; Chauvat, M.; Wolters, V. Spruce forest conversion to a mixed beech-coniferous stand modifies oribatid community structure. Appl. Soil Eco. 2014, 76, 60-67.

45. Paquin, P. Carabid beetle (Coleoptera: Carabidae) diversity in the black spruce succession of eastern Canada. Biol. Conserv. 2008, 141, 261-275.

46. Paradis, S. Évaluation de l'effet des Coupes Partielles sur les Arthropodes Terricoles dans des Peuplements D'épinette noire Sujets à la Paludification. Ph. D. Thesis, Université du Québec à Montréal, Montreal, Canada, 2010.

47. Migge, S.; Maraun, M.; Scheu, S.; Schaefer, M. The oribatid mite community (Acarina) of pure and mixed stands of beech (Fagus sylvatica) and spruce (Picea abies) of different age. Appl. Soil Ecol. 1998, 9, 115-121.

48. Zaitsev, A.S.; Chauvat, M.; Pflug, A.; Wolters, V. Oribatid mite diversity and community dynamics in a spruce chronosequence. Soil Biol. Biochem. 2002, 34, 1919-1927.

49. Salmon, S.; Artuso, N.; Frizzera, L.; Zampedri, R. Relationships between soil fauna communities and humus forms: Response to forest dynamics and solar radiation. Soil Biol. Biochem. 2008, 40, $1707-1715$.

50. Wang, C.; Bond-Lamberty, B.; Gower, S.T. Environmental controls on carbon dioxide flux from black spruce coarse woody debris. Oecologia 2002, 132, 374-381.

51. Seastedt, T.R.; Reddy, M.V.; Cline, S.P. Microarthropods in decaying wood from temperate coniferous and deciduous forests. Pedobiologia 1989, 33, 69-77.

52. Zak, D.R.; Groffman, P.M.; Pregitzer, K.S.; Christensen, S.; Tiedje, J.M. The vernal dam: Plant-microbe competition for nitrogen in Northern hardwood forests. Ecology 1990, 71, 651-656.

53. Fenton, N.; Lecomte, N.; Légaré, S.; Bergeron, Y. Paludification in black spruce (Picea mariana) forests of eastern Canada: Potential factors and management implications. For. Ecol. Manag. 2005, 213, 151-159.

54. Skubała, P.; Sokołowska, M. Oribatid fauna (Acari, Oribatida) in fallen spruce trees in the Babia Góra National Park. Biol. Lett. 2006, 43, 243-248.

55. Siira-Pietikainen, A.; Penttinen, R.; Huhta, V. Oribatid mites (Acari:Oribatida) in boreal forest floor and decaying wood. Pedobiologia 2008, 52, 111-118.

56. Nielsen, U.N.; Osler, G.H.R.; van der Wal, R.; Campbell, C.D.; Burslem, D.F.R.P. Soil pore volume and the abundance of soil mites in two contrasting habitats. Soil Biol. Biochem. 2008, 40, 1538-1541. 
57. Lindberg, N.; Bengtsson, J.B.; Persson, T. Effects of experimental irrigation and drought on the composition and diversity of soil fauna in a coniferous stand. J. Appl. Ecol. 2002, 39, 924-936.

58. Tsiafouli, M.A.; Kallimanis, A.S.; Katana, E.; Stamou, G.P.; Sgardelis, S.P. Responses of soil microarthropods to experimental short-term manipulations of soil moisture. Appl. Soil Ecol. 2005, 29, 17-26.

59. Siepel, $H$. The importance of unpredictable and short-term environmental extremes for biodiversity in oribatid mites. Biodiv. Let. 1996, 3, 26-34.

60. Read, D.J.; Leake, J.R.; Perez-Moreno, J. Mycorrhizal fungi as drivers of ecosystem processes in heathland and boreal forest biomes. Can. J. Bot. 2004, 82, 1243-1263.

(C) 2015 by the authors; licensee MDPI, Basel, Switzerland. This article is an open access article distributed under the terms and conditions of the Creative Commons Attribution license (http://creativecommons.org/licenses/by/4.0/). 